\title{
Problems and Solution on the New-type Rural Endowment Insurance in Hebei Province of China
}

\author{
Yanfang $\mathrm{Gu}$ \\ School of Management, Hebei University \\ No.180 Wusi Easter Road, Baoding 071002, Hebei Province, China \\ Hongbo Duan \\ PHD, University Utara of Malaysia, Sintok, Kedah, Malaysia \\ E-mail: duanhongbocn@126.com \\ Prof. Dr. Abdul Razak bin Chik \\ University Utara of Malaysia, Sintok, Kedah, Malaysia
}

Received: July 28, 2011 Accepted: August 24, 2011 doi:10.5539/jms.v1n1p147

The research is supported by the project of "Over-all Social guarantee System in Urban and Rural Areas: Implement Obstacles, Route Dependence, and System Arrangement" of Hebei Provincial Social Science Fund of 2009 (No. HBO9BSH004)

\begin{abstract}
This Paper based on the statistical and research data, analysis the present situation of new-type rural endowment insurance in Hebei province of China, proposed countermeasures to improve the operation mechanism, promote the development of new rural endowment insurance in Hebei province, improving social welfare and happiness, conducive to the harmonious development of society.
\end{abstract}

Keywords: Social security fund, Enter security market, Risks control

\section{Preface}

The new-type rural endowment insurance is a great benefiting-farmers policy following the abolishment of Agricultural Tax, direct allowance for grain and the establishment of new-type rural cooperative medical insurance system.

In 2009, 18 counties were selected as first experimental units of the new-type rural endowment insurance, involving 6.883 million rural citizens. On October 19th 2010, provincial human resources and social security bureau announced the list of the second 19 experimental units, and the start time was October 1st, 2010. The aim of complete coverage for the rural residents of the right age will be basically achieved Before 2020 .

\section{Literature review}

\subsection{Foreign research status}

Foreign scholars seldom focus on the research of rural social endowment insurance in China. The World Bank (1998) proposed "three pillars" and the "five pillars" mode old-age of security system. D. Gale Johnson (1999) supposed that rural families in China after decades of pension will not be able to maintain the trend through the analysis of household survey in Sichuan and Liaoning provinces in 1990s based on data 1993-1998. At the same time, Jack (2005) noted the necessity to establish the formal social security system. China with most farmers in the world, but without land ownership, farmers cannot sell the land to meet their retirement needs.

\subsection{Domestic research status}

More and more scholars have studied on China's rural endowment insurance system since 1998. Wang GuoJun (2002) advocated establishing three-level system. First covers the supplementary protection for urban and rural 
areas; second, according to the local conditions to promote, covers additional safeguards coordinated by the provinces; third mainly depends on commercial guarantees. Gao Shusheng (2007) indicated "third way" can't afford social security in China. It can only implement the special social security, and pension and health care are two major projects. Tan Kejian (2006) advocated that complete social security system was a combination of mechanisms, and pointed out that in the old-age social security mechanisms, community social security and family endowment insurance mechanism are the most important. Zheng Gongcheng (2008) established five-level model, and advocated the primary responsibility of the Government should be assumed, focusing on the basic endowment insurance system of the Government hierarchy.

\section{The current condition of new-type rural endowment insurance in Hebei}

\subsection{Conditions of the first experimental region}

By the end of September 2010, there are totally 3.937 million people in those 18 counties and cities insured and insurance rate was $92.27 \%$. Among them, 3.1011 million people were at the age of 16 to 59 , making a collection of premium 800.2078 million yuan; 839.5 thousand rural citizens over 60 years old have received pensions totally 608.98 million yuan, 72.8 yuan per capita a month. The goal of complete coverage was basically achieved.

\subsection{Current situation on second trials of new-type rural endowment insurance in Hebei Province}

Since then, 37 counties cities and districts in the province, approved by the state, launched the experiment on new-type rural endowment insurance, involving 12.5173 million rural citizens, accounting for 25.24 percent of the province's rural citizens. The number of rural citizens over 60 years old involved in the trial is 1.5695 million, accounting for 23.98 percent of all rural population, above the national average level. At present, 37 experimental units have started premium collection and pension distribution.An initial success has been made.

\section{Problems of new-type rural endowment insurance in Hebei}

Since the new-type rural endowment insurance is a complex social systems project, with its long-term, sensitivity and complexity, there are many problems in the process of promoting the trial.

\subsection{Problems on financing}

The three financing sources of new-type rural endowment insurance are individual payment, collective subsidy and local financial subsidy.

\subsubsection{Individual payment}

According to the "suggestion" of new-type rural endowment insurance in Hebei, individual payment is set in five grades: 100yuan, 200yuan, 300yuan, 400yuan and 500yuan, which is $2 \sim 10$ percent of net per capita income. In 2009, per capita net income of rural residents in Hebei was 5,150yuan and per capita living expenditures was 3,350 yuan over the same period. Per capita disposable income was around 1800yuan, about 35 percent of per capita net income.

It can be worked out that the ratio of premium to per capita disposable income are $5.56 \%, 11.11 \%, 16.67 \%$, $22.22 \%$ and $27.78 \%$. Although paying 5 25 percent of disposable income for the insurance will not have a great impact on the surplus income of peasants, but for those living in extreme poverty with low-income, it is relatively difficult. See table 2 and chart 2 .

\subsubsection{Collective subsidy}

In "suggestions" of new-type rural endowment insurance, rural enterprises should increase subsidy on insurance payment for its rural employees. Because of the imbalanced economic development in our province, rural collective in some economically developed regions, rural-urban fringe zone or resource - rich region for example, may support the new-type rural endowment insurance system by transferring collective land and mineral resources. But most of the rural areas does not have the ability to subsidize the insurance system, which means collective subsidy has a very limited contribution to the financing of new-type rural endowment insurance.

\subsubsection{Local financial subsidy}

According to the "suggestions", each insurant will receive 30yuan as subsidy per year. For people with severe disability, their 81 yuan premium should be paid by the government annually. Province city and county share the financial burden of subsidizing the insured and the disabled equally. In counties directly under the jurisdiction of provincial government, province and county both share half of the burden. The first trial on new-type rural endowment insurance in Hebei involves 3.1011 million people, 30yuan subsidy per head as counted, total financial subsidies at all levels reaches 93.033 million yuan. After the second trial started, with 12.5173 million rural residents involved in, direct beneficiary more than 60 years old excluded, the number of insurants at the 
right age is 900 million, the pertinent scale of financial subsidies will be 270 million yuan.

Once severely disabled group, family planning households and other special groups were taken into account, financial subsidy size will be even greater. In accordance with the sharing ratio, county level fiscal expenditure will be more than 100 million. This will undoubtedly cause a heavy financial burden to some poverty - stricken counties.

\subsection{Individual account was not scientifically designed}

The amount of pension each insurant received is the total savings in individual account divided by 139 , monthly dispensing coefficient is 0.0071942 (the same coefficient with basic endowment insurance for urban workers) The number 139 is based on the prediction of life expectancy left for rural residents over 60 years old. That is to say, for those rural residents their savings of personal account will be withdrew in 11.6 years, that is, when they are 72 years old, their individual account storage volume would be zero. If the insurant is still alive after 70 years old,the government pays for their pension. According to statistics of the country's population life expectancy, at this stage, life expectancy of 60 -year-old rural residents is 20.62 years, and 11.6 years for the 72 -year-old. When there is no savings in individual account at the age of 72 , the government has to shoulder the expenditure of pension for those who lives longer than 72 years. The government has to bear the expense for 12 years. This is a large sum of money and may become a major potential financial pressure, but no such system is set up to release the pressure in Hebei province

\subsection{Incentive mechanism in the design of individual account is not deterministic}

There is no such "the more you pay, the more you get" incentive mechanism. Every insurant obtains an annual subsidy of 30yuan from the insurance system, no matter how much they've paid. In other words, if one selected $100 y u a n$ as his payment standard, he would receive 30yuan subsidy, subsidized rate is $30 \%$. However, if a insurant selected 500yuan standard, he could only receive 30yuan as well, subsidy rate is only $6 \%$. In this case, there will be an "adverse choice", that is, most people would choose the 100yuan standard, instead of a higher level of payment standard, because the higher the standard you choose, the greater potential losses there will be. Secondly, there is a lack of preferential policy for people who have long period of fee-paying in the system. In Table 3 , for insurats aged $30,45,50,59$, the annual payment is 100 yuan. If the annual interest rate is $3 \%$, we can see that it takes less time for people under 45 years old to cover their cost than those aged between 45 and 60 . For the latter, the closer you age is away from the pension receiving age, the shorter it takes to cover your cost ,therefore, the pension payment policy of new-type rural endowment insurance has a great attraction to the elderly people in rural areas, but not that big to the young. It is the result of the absence of incentive mechanism to encourage insurants to pay more so than they can get more.

\subsection{Service system is not perfect}

At present, the rural insurance office newly set by provincial agency in Hebei province has two staff temporarily transferred from other position, their working environment is very poor. In order to carry out the work, some experimental units set up rural insurance center, others through insurance agencies. Departments handling the insurance at grass-roots level are understaffed, and they are faced with the problem of imperfect construction of organization. In most cases, the accountant or secretary of the Party branch in a village undertakes the insurance affairs as a part-time jobs unpaid. From table 4, we can see that, in county-level agencies each office-bearer serves 30,000 person-times, and some even as high as 70000 person-times. Heavy workload together with extremely underdeveloped information system brings tremendous difficulties to the agencies.

\section{Countermeasure on improving operation mechanism of new-type rural endowment insurance}

Whether the new farmers' insurance system is effective or not can be judged in three aspects: scientific computation, entirely insured and insure as needed. "Scientific computation" means that new farmers' insurance system should be based on scientific and effective actuarial science, just like other social insurance system. "entirely insured" indicates that in the process of implementation, all groups supposed to be secured can enjoy pension fairly. "insure as needed" points out that in the future we should innovate upon methods of farmers' insurance in the light of the changes in rural social and economic structure, as well as the needs of rural residents.

\subsection{Strengthen the fund - raising ability of social security, and guarantee its feasibility in the long term}

4.1.1 Increase farmers' incomes and capacity to pay for the insurance

At present, premium at all levels takes up about $6 \%$ to $27 \%$ of farmers' disposable income. Influenced by disposable income, most insurants choose lower premium level, which is 100yuan to 300yuan. 500yuan 
premium accounts for $27 \%$ of the income; this ratio is higher than that in other countries. It is calculated that once the income of farmers increases $1 \%$, their capacity to pay will rises $18 \%$. So new farms' insurance and the growth of the farmers' income help each other forward. In the course of trial ahead, exploring ways to increase farmers' income actively is crucial to the continuity of new farm's insurance system.

\subsubsection{Increase collective subsidy}

As can be seen from the trail, most individual payment centers on 100yuan and 200yuan. But if the collective subsidy rises, insurants would choose a higher premium level. Take a village in Shahe city as an example. with its mining revenues, the village collective subsidizes 500yuan to every insurant annually, which greatly arose the enthusiasm of farmer. Within half a month, a $100 \%$ coverage of the insurance turned into reality. Increasing collective subsidy and attracting more subsidy from non - governmental organizations and individuals contribute to not only the rise of farmers' enthusiasm, but also the increase of payment level. Farmers could enjoy spending their remaining years in happiness.

\subsubsection{Ensure the financial support}

Hebei needs to improve the mechanism of financial responsibility at all levels and restricts government subsidizing all levels by system. One is to improve the new rural financial subsidy budget mechanism. Farmers' insurance subsidies being listed in the financial budget is an effective way to make financial subsidy effective and stable. Second is to establish constraint mechanism on the implement of financial subsidy at all levels as soon as possible. As the trail develops, an increasing number of people become insurants. Together with adjustments on some encouragement policies, the amount of financial subsidy at all levels grows bigger and bigger, and finance is now facing an increasing pressure. It is even more difficult for the underdeveloped areas. If there are no strict financial constraint mechanism, there may use the current money in the individual account as the current fiscal subsidy, resulting in an empty individual account. The intergenerational support is in fact accounting on a cash basis, which goes against the original intention of the new farmers' insurance system design.

\subsection{Design the individual account scientifically, and relieve government's financial pressure}

With the improvement of living standard and progress of medical science, lifetime of rural residents in Hebei increases. Therefore we should adjust the number of months during which period pension is provided on the basis of changing situation. Only by scientific computing and adjustment on pension standards could release financial pressure of the government. Assuming that an insurant's life expectancy is 75 years old at the age of 60 , all pension in its individual account will be given out in 139 months. After that the government needs to pay the remaining pension of 41 months. If the number of pension would be given out in 150 months, that is, life expectancy is 72.5 years, then the government pays the remaining pensions of 30 months. Once the number of months is adjusted from 139 to 150, changes in the volume of individual account are listed as the following in table 5 .

Take a farmer who covers insurance at 30 years old as an example, the balance of his individual account would be around 38 at the age of 60 . As can be seen from the table above, after the adjustment, there will be a difference of less than 2yuan on pension per month in individual account. But the government will pay nearly 22 yuan less. So adjusting the number of pension months is an effective way to release government's fiscal pressure. But this adjustment should be controlled in a reasonable extent, if the adjustment was too big, it would affect the insured person's pension level and reduce benefits of the insurants, which is against the original intention of the implementation of the new farmers' insurance system.

\subsection{Speed up the formulation of cohesive device, and establish the foundation of integration on social security}

Hebei province should establish provincial cohesive device to ensure a smooth link and transition between the systems and promote the realization of integration of urban and rural social endowment insurance systems. Disunity on cohesive device may cause unfairness to the change of systems, on the contrary, unity of the system will help enhance the efficiency of agencies and reduce localization and fragmentation. It will help in establishing integrated urban and rural social endowment insurance system all over province in the future. Facing the reality that regions have their own understanding and inplementing regulations to the system, the provincial social security departments should implement a unified plan as soon as possible. The Link to the old farmers'insurance system can be taken by gradually "disposing" policy. In the matter of the existence of huge difference on the unification of individual accounts in different areas, we should use a unified working method without discount time. Facing the differences in treatment appeared, we should explain policy to the insurants to minimize "transformation costs". Transverse communication with other related departments should be 
accelerated and specific feasible proposals to the convergence of the new farmers' insurance policies with other policies should be put forward as soon as possible. Accelerate the study on convergence of trails with the "Suggestions" in advance and solve the problems during the transitional period properly.

\subsection{Implement the system of incentive mechanism to improve the initiative of the insured}

To make the system more attractive essentially, we must add the design which encourages young and middle-aged people to be insured to the policy. Here are three plans: set up a gradient subsidy standard. Government subsidy for the 100yuan standard is 30yuan. There will be a rise in subsidy according to a certain ratio for a higher premium standard; set up a "pay more and get more" mechanism. For people who have paid for more than 15 years, for each more additional year, there will be an additional certain amount of government subsidy or a subsidy of a certain percentage of the standard. Through this system design, increase young and middle-aged farmers' enthusiasm for the insurance and raise the premium standard so as to increase the accumulation of individual account and improve the indemnification of the new farms' insurance.

\subsection{Reform the personnel management system, and improve the overall service capability}

Trail of New farmers' insurance, to a great extent, is to test the management and services except for the policy an financial resource testing. Handling relies on policy for a clear direction, and policy needs handling for its specific implementation. The two are mutually complementary and indispensable. Improve the services capacity of the new farmers' insurance through two channels: one is through the standardization of working position. It is an expression of specialization, schematization, standardization and institutionalization. Requirement of standardization on manpower and resources is relatively high, therefore we should regard the beginning of trial on the new farmers' insurance system as an opportunity to study and formulate standardized working process, specification mode of establishing agencies and staffing and funding guarantee mechanisms. The second is to speed up the construction of informatization. It is necessary to establish a high level data sharing system, and speed up the exploitation and construction of software and hardware as soon as possible. In order to adapt to the construction of informatization, we need more investment and a proper allocation of resources with the help of informationization "social security informationization project".

\section{Target and forward-looking on Hebei Province "New farmers' insurance"}

\subsection{Development goals of Hebei Province "New farmers' insurance"}

For the development direction of the old-age insurance system in rural areas in Hebei province, we can take the "three-step" strategy: first, from now to 2013, dovetail the new and old farmers' insurance systems. On the basis of properly handling of the old farmer security fund debt issue, dovetail the two farmers' insurance system and guide farmers voluntarily join the new farmers' insurance actively in order to implement the new-type rural endowment insurance system in all rural areas in the province. Second step, from 2014 to 2017, implement the convergence of the rural old-age insurance with other social security systems in rural areas, properly handle the convergence of the new farmers' insurance system and rural family planning supporting policy, rural Five Guarantees supporting system and rural minimum living standard security system. Implement a social security system covering all rural areas in Hebei Provincethird by 2020 and eventually implement a steady establishment of social security system in urban and rural areas, and integrated them into a national one.

\subsection{Forward-looking on Hebei Province "New farmers' insurance"}

\subsubsection{There will be a financial pressureIf if the realization of complete coverage in advance}

In fact, in early 2010, all cities and counties in Tangshan city Hebei province has established a new farmers' insurance system. Some counties in Langfang and Cangzhou have their own implementation scheme of the new-type rural endowment insurance sent to the provinceserve as a record At present, coverage of the new farmers' insurance in Hebei province is more than 10\%, and with the development of pilot work, it is possible to implement the full coverage all over the province in advance before 2020. Hebei Province should foresee this trend and think about if the realization of complete coverage achieved early than thought, would the finance able to withstand the pressure.

As can be seen from table 6, assume that there is no rise in the amount of government subsidy, the earlier complete coverage is realized, the greater financial pressure there will be. If the complete coverage realizes 4 years in advance, the local financial subsidy accounts for $0.35 \%$ of fiscal revenue each year. If it is 2 years in advance, the government subsidy funds accounts for $0.32 \%$ of fiscal revenue. Therefore, provincial and city level finance needs to consider the prospect of the development of the system, adjust the province's the city's budget plan, and guarantee new farmers' insurance system in rural areas, turning the goal " the old - age do not worry about retirement " into reality. 


\subsubsection{Limited ability to ensure pension in the future}

The central finance pays 55yuan basic pension for each insurant per month, 660yuan a year in total. Using the province's rural per capita annual net income of 5,000yuan for calculation, its basic pension substitute rate is $13.2 \%$, while the lowest rate of substitution of basic old-age insurance in cities and towns is $20 \%$.

According to data in table 6, suppose that a farmer join in the insurance at the age of 30 and select the100yuan payment standard, paying 15 year in a row, local government subsidizes 30yuan per year. When he is 60 years old, his individual account balance is 3,767yuan, the monthly amount of pension in individual account is $27 y u a n$, a total of 324yuan a year. Its individual account pension substitute rate is $6.5 \%$, that is, the total substitute rate of basic pensions and individual account pension is around $20 \%$.

At present, the pension of the new farmers' insurance can maintain the most basic living standard in rural areas, however, with the increase on the per capita annual net income in rural areas and a lot of young people getting out of rural areas, old rural residents may have a desperate demand on life service not money. The "uniformity" of new rural farmers' insurance system will be challenged.

\section{References}

Agenda (2009) An Assessment of Poverty and Inequality in China.

Analysis.The World Bank Policy Research Working Paper, 2001.

Chen Jiagui, and Wang Yanzhong (2004). Social Security Report of China (2001-2004). Social Sciences Academic Press.

Chen Jiagui (2001). Social Security Report of China (1997-2001). Social Sciences Academic Press.

Cost, Options and Impact of China's Pension Reform a Computable General Equilibrium.

World Bank, From Poor Areas to Poor People: China's Evolving Poverty Reduction.

Xin Ling (2003). Several Understanding Mistakes of Social Security Fund Entering Market. Contemporary Economic.

Yan Wang, Dianqing Xu, Zhi Wang, \& Fan Zhai. Implicit Pension Debt. Transition.

Yang Y., Williamson, J. B., and Shen, C (2009). Social Security for China's Rural Aged: A Proposal Based on a Universal Non-Contributory Pension. International Journal of Social Welfare, Vo1.18.

Table 1. Difference on Income and Living Expenditure between Urban and Rural Areas 2001--2009

\begin{tabular}{|c|c|c|c|c|}
\hline year & $\begin{array}{c}\text { Net income } \\
\text { of farms } \\
\text { (ten thousand } \\
\text { yuan) }\end{array}$ & $\begin{array}{c}\text { Average living } \\
\text { expenditure of } \\
\text { rural residents } \\
\text { (ten thousand } \\
\text { yuan) }\end{array}$ & $\begin{array}{c}\text { Remaining income } \\
\text { living expenditure } \\
\text { deducted } \\
\text { (ten thousand yuan) }\end{array}$ & $\begin{array}{c}\text { rural family } \\
\text { Engel's coefficients. } \\
\text { (\%) }\end{array}$ \\
\hline 2001 & 2603.6 & 1912 & 691.6 & 47.7 \\
\hline 2002 & 2685.16 & 1987 & 698.16 & 46.2 \\
\hline 2003 & 2853.29 & 2042 & 811.29 & 45.6 \\
\hline 2004 & 3171.06 & 2167 & 1004.06 & 47.2 \\
\hline 2005 & 3481.64 & 2449 & 1032.64 & 45.5 \\
\hline 2006 & 3801.8 & 2495 & 1306.4 & 43 \\
\hline 2007 & 4293.4 & 2787 & 1506.4 & 43.1 \\
\hline 2008 & 4795 & 3126 & 1669 & 38.2 \\
\hline 2009 & 5150 & 3350 & 1800 & 35.7 \\
\hline
\end{tabular}

Data sources: Economic Yearbook of Hebei province 2009. Statistics Bureau of Hebei Province: Economic Yearbook of China 2008; Statistical Report on National Economy and Social Development of Hebei province 2008. 
Table 2. Comparison on Pension Standard for Different Ages

\begin{tabular}{|c|c|c|c|c|c|c|}
\hline $\begin{array}{c}\text { insured } \\
\text { age }\end{array}$ & $\begin{array}{c}\text { premium } \\
\text { standard } \\
\text { (yuan) }\end{array}$ & $\begin{array}{c}\text { payment } \\
\text { Period } \\
\text { (year) }\end{array}$ & $\begin{array}{c}\text { total } \\
\text { premium } \\
\text { (yuan) }\end{array}$ & $\begin{array}{c}\text { balance of } \\
\text { individual } \\
\text { account at the } \\
\text { age of } 60 \text { (yuan) }\end{array}$ & $\begin{array}{c}\text { pension } \\
\text { Per month } \\
\text { (yuan) }\end{array}$ & $\begin{array}{c}\text { time to cover } \\
\text { the cost } \\
\text { (year) }\end{array}$ \\
\hline 30 & 100 & 30 & 3000 & 3766.942 & 82.100 & 1.52 \\
\hline 45 & 100 & 15 & 1500 & 2417.857 & 72.395 & 1.72 \\
\hline 50 & 100 & 10 & 1000 & 1490.307 & 65.722 & 1.27 \\
\hline
\end{tabular}

Data sources: calculated according to the standard of new farmers' insurances and bank interest rates

Table 3. Person-Time of Services in Some Experimental Units of New-Type Rural Endowment Insurance in Hebei Province

\begin{tabular}{|c|c|c|c|}
\hline experimental unit & $\begin{array}{c}\text { population } \\
\text { (ten thousand people) }\end{array}$ & $\begin{array}{c}\text { number of staff in } \\
\text { county-level new farms' } \\
\text { insurance agency } \\
\text { (person) }\end{array}$ & person-time ratio \\
\hline Xuning county & 24.3 & 8 & $30375: 1$ \\
\hline Zaoqiang county & 32.7 & 12 & $27250: 1$ \\
\hline Shahe city & 29.4 & 4 & $73500: 1$ \\
\hline
\end{tabular}

Data sources: calculated according to work reports of new farmers' insurance in experimental units

Table 4. Comparison of Adjustment on Number of Pension Distribution Months

\begin{tabular}{|c|c|c|c|c|}
\hline age got insured & 30 & 45 & 50 & 59 \\
\hline premium standard (yuan) & 100 & 100 & 100 & 100 \\
\hline payment Period (year) & 5 & 15 & 10 & 1 \\
\hline total premium (yuan) & 1500 & 1500 & 1000 & 100 \\
\hline balance of individual account at the age of 60 (yuan) & 3766.94 & 2417.86 & 1490.31 & 137.92 \\
\hline pension distribution month is 139 & 27.10 & 17.39 & 10.72 & 0.99 \\
\hline pension distribution month is 150 & 25.11 & 16.12 & 9.94 & 0.92 \\
\hline reduce of pension in individual account (yuan) & 1.99 & 1.28 & 0.79 & 0.07 \\
\hline number of months government pays less & 11.00 & 11.00 & 11.00 & 11.00 \\
\hline amount of money government saves (yuan) & 21.86 & 14.03 & 8.65 & 0.80 \\
\hline
\end{tabular}

Data sources: according to different standard in the suggestion

Table 5. Forecast on Financial Support of Complete Coverage in Advance

\begin{tabular}{|c|c|c|c|c|}
\hline year & $\begin{array}{c}\text { expected financial } \\
\text { revenue is (100 million } \\
\text { yuan) }\end{array}$ & $\begin{array}{c}\text { Population } \\
\text { involved (person) }\end{array}$ & $\begin{array}{c}\text { amount of financial } \\
\text { subsidy (100 million } \\
\text { yuan) }\end{array}$ & Share (\%) \\
\hline 2012 & 2835.29 & 40539757 & 12.16 & 0.43 \\
\hline 2014 & 3556.58 & 46024391 & 13.81 & 0.39 \\
\hline 2016 & 4461.38 & 52251043 & 15.68 & 0.35 \\
\hline 2018 & 5596.35 & 59320099 & 17.80 & 0.32 \\
\hline 2020 & 7020.06 & 67345531 & 20.20 & 0.29 \\
\hline
\end{tabular}

Data sources: predicted according to the Hebei provincial economic statistics yearbook 